\title{
Quantification of Greenhouse Gas Emissions from the Predisposal Stage of Municipal Solid Waste Management
}

\author{
Chuanbin Zhou, ${ }^{*}, * \odot$ Daqian Jiang," and Zhilan Zhao ${ }^{\dagger}$ \\ ${ }^{\dagger}$ State Key Laboratory of Urban and Regional Ecology, Research Center for Eco- Environmental Science, Chinese Academy of \\ Sciences, 18 Shuangqing Road, Haidian District, Beijing100085, China \\ ${ }^{\ddagger}$ Center for Industrial Ecology, School of Forestry and Environmental Studies, Yale University, 195 Prospect Street, New Haven, \\ Connecticut 06511, United States
}

\section{Supporting Information}

\begin{abstract}
Municipal solid waste (MSW) disposal represents one of the largest sources of anthropogenic greenhouse gas (GHG) emissions. However, the biogenic GHG emissions in the predisposal stage of MSW management (i.e., the time from waste being dropped off in community or household garbage bins to being transported to disposal sites) are excluded from the IPCC inventory methodology and rarely discussed in academic literature. Herein, we quantify the effluxes of carbon dioxide $\left(\mathrm{CO}_{2}\right)$, methane $\left(\mathrm{CH}_{4}\right)$, and nitrous oxide $\left(\mathrm{N}_{2} \mathrm{O}\right)$ from garbage bins in five communities along the urban-rural gradient in Beijing in four seasons. We find that the annual average $\mathrm{CO}_{2}, \mathrm{CH}_{4}$, and $\mathrm{N}_{2} \mathrm{O}$ effluxes in the predisposal stage were $(1.6 \pm 0.9) 10^{3}, 0.049 \pm 0.016$, and $0.94 \pm 0.54 \mathrm{mg} \mathrm{kg}^{-1} \mathrm{~h}^{-1}$ (dry matter basis) and had significant seasonal differences (24- to 159 -fold) that were strongly correlated with temperature. According to our estimate, the $\mathrm{N}_{2} \mathrm{O}$ emission in the MSW predisposal stage amounts to $20 \%$ of that in the disposal stage in Beijing, making the predisposal stage a nontrivial source of waste-induced $\mathrm{N}_{2} \mathrm{O}$ emissions. Furthermore, the $\mathrm{CO}_{2}$ and $\mathrm{CH}_{4}$ emissions in the MSW predisposal account for 5\% (maximum $10 \%$ in summer) of the total carbon contents in a Beijing's household food waste stream, which has significance in the assessment of MSW-related renewable energy potential and urban carbon cycles.

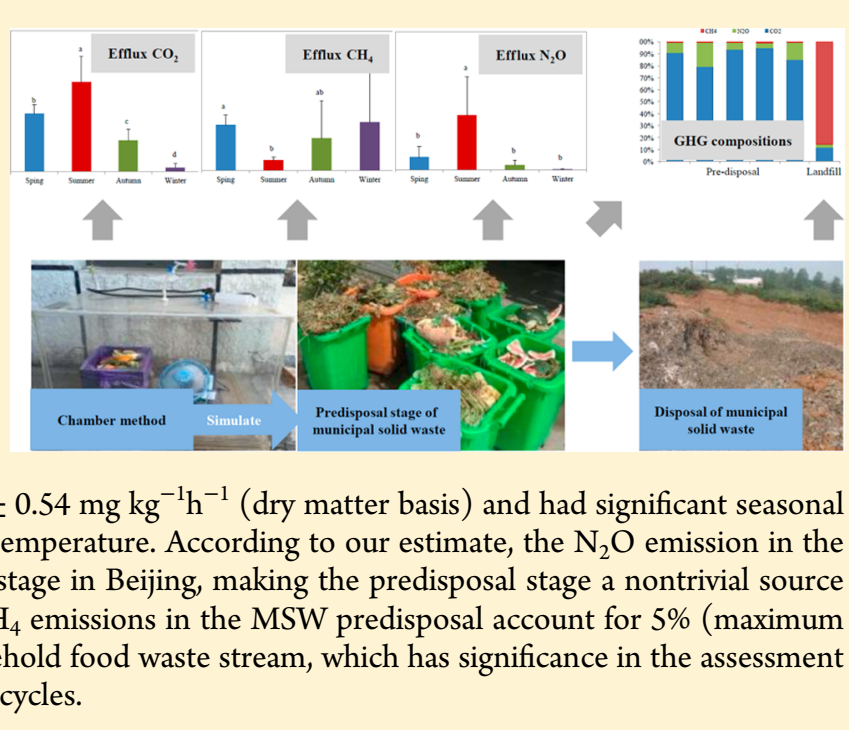

\section{INTRODUCTION}

Municipal solid waste (MSW) management is not only crucial to urban environmental quality and material recycling but is also one of the largest sources of greenhouse gas (GHG) emissions from human settlements. ${ }^{1,2}$ According to the Intergovernmental Panel on Climate Change (IPCC), global waste disposal is responsible for 1446 million tons of GHG emissions in 2010 and has seen an increase of $13 \%$ between 2000 and $2010 .^{3}$ In 2005, GHG emissions from the waste sector amounted to 112 and 178 million tons $\mathrm{CO}_{2}$ eq in China and in the United States, respectively, which show the significant GHG impact of the waste sector in both developing and developed countries. ${ }^{2,4}$ In addition, waste disposal is often one of the largest sources of anthropogenic methane emissions, which is the second largest category of GHGs and 25 times more potent than $\mathrm{CO}_{2}{ }^{2,3}$

A breadth of studies has examined the GHG emissions from MSW management at different scales. At the regional and national scales, GHG emissions from MSW disposal sites in Africa, United States, Europe, and China were calculated to provide scientific evidence for setting GHG reduction targets. ${ }^{1,5-8}$ Similar efforts were made at the city scale to help understand the environmental impacts of $\mathrm{MSW}^{9,10}$ or choose mitigation technologies and strategies. ${ }^{10-12}$ At the site scale, experimental studies have been conducted to quantify the amounts and trends of GHG emissions from centralized disposal sites ${ }^{13-16}$ and decentralized organic waste treatment facilities (e.g., home composting of source-separated organics $^{17-22}$ ) to understand the mechanisms or obtain highresolution emissions data.

Most of these studies have adopted the widely followed IPCC inventory methodology, which focuses on the GHG emissions from disposal sites and underemphasizes the predisposal stage (i.e., the time from when the waste is dropped off in community or household garbage bins to the time it is transported to disposal sites). ${ }^{23}$ Literature pertaining to the predisposal stage of MSW management only examined the GHG emissions from the fossil fuel consumption in the MSW collection and transportation, ${ }^{9,12,24,25}$ without paying attention to the direct, biogenic GHG effluxes. However, in the predisposal stage, MSW is often dropped off and stored in garbage bins in households and communities for a considerable amount of time before being collected and transported to waste

Received: October 12, 2016

Revised: December 7, 2016

Accepted: December 12, 2016

Published: December 12, 2016 
disposal sites (i.e., landfills and incinerators). ${ }^{26}$ In China, this predisposal stage can take up to 2 days in urban areas and much longer in rural areas with no regular clearing service. ${ }^{27}$ In the United States, the curbside collection service for MSW and separated organic waste is normally offered weekly or biweekly for cost considerations. ${ }^{28-30}$ During this time, the garbage bins provide an ideal environment for biogenic GHG emissions given the moderate temperature, presence of oxygen, active microorganisms, and large quantities of biodegradable matters (e.g., biodegradable food waste accounts for $40.0 \%$ to $73.7 \%$ of the total MSW in China). ${ }^{27,31,32}$ The conditions of the predisposal stage are somewhat similar to home composting, in which significant amounts of methane and nitrous oxide emissions were found. ${ }^{18,22}$ Despite the favorable conditions, the biogenic GHG emissions of MSW in the predisposal stage have not been systemically studied.

In this study, we attempt to fill this knowledge gap by monitoring the biogenic GHG emissions from MSW in the predisposal stage. Using the chamber method, ${ }^{16,20,21}$ we did high-resolution profiling of the GHG effluxes from 50 households in five communities along the urban-rural gradient of the Beijing metropolitan area. We found that the biogenic GHG emissions in the predisposal stage was nontrivial and had potentially significant seasonal and cross-community differences. Our results call attention to the potential climate change impact of this overlooked MSW management stage that may be worthy of further studies.

\section{MATERIAL AND METHODS}

2.1. Description of Study Sites. The study was done in Beijing, which has a population around 21.15 million and generated a total of 6.72 million tons of MSW in $2013 .{ }^{33} \mathrm{~A}$ large proportion of Beijing's MSW is biodegradable food waste $(64 \%-67 \%)$ that can potentially result in high biogenic GHG effluxes. $^{34}$

Five communities along the urban-rural gradient of the Beijing metropolitan area were selected for this study, which were representative of the location (old city, new built city, suburbs, and village), type and age of the buildings (story and built year), socio-economic status, and demographics of typical residential communities in Beijing. For each community, 10 households were randomly selected. A questionnaire was given to each household to collect background information on demographics, income, food expenditures, MSW drop-off habits, and source separation behaviors. The location and the socio-economic profiles of the five communities are shown in Figure 1. Generally, the Jinmaoyue community (in new built city) has the highest average income. The Shaojiu and Huangtugang communities have middle income. The Zhux have the lowest income, largest family population, and highest percentage of income spent on food. More details of the communities can be inzhuang (suburb) and Shuiyuzui (rural village) communities found in Table S1 of the Supporting Information.

The questionnaire results indicated that on average MSW stayed inside the households for 1 day before being dropped off in the community garbage bins. The Regulation of Beijing Municipality on City Appearance and Environmental Sanitation requests a daily collection and clearance of MSW in urban area. Therefore, in this work, we assumed that the duration of the predisposal stage was 2 days in Beijing.

2.2. Sampling and Waste Composition Characterization. MSW from each community was sampled once each

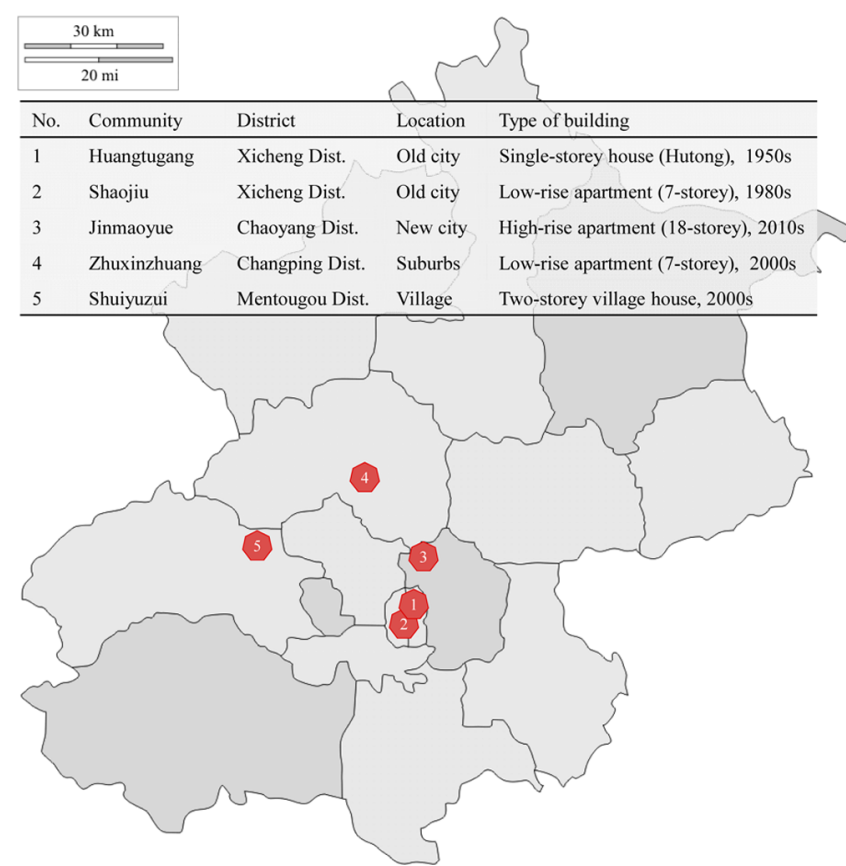

Figure 1. Locations of the studied communities along an urban-rural gradient in Beijing, China.

season. The five communities were sampled sequentially in each season, and the entire sampling and monitoring were completed in 2 weeks. The sampling dates were as follows: spring, from April 12-26, 2015; summer, from July 7-28, 2015; autumn, from October 19-November 7, 2015; winter, from January 8-23, 2016. Given the relatively short time frame of the predisposal stage (around 2 days in Beijing), only MSW that can be rapidly biodegraded was collected. The selection of biodegradable MSW was based on previous studies ${ }^{30,35}$ and included five main categories, namely, rice and wheat, vegetable, fruit, meat waste, and other biodegradable fractions.

In each experiment, around $15-20 \mathrm{~kg}$ of biodegradable fractions of MSW was collected from 10 households in each community. The collected waste was thoroughly mixed, and two $3 \mathrm{~kg}$ mixtures were taken by using the coning and quartering method for further analysis: One mixture was used for GHG emission quantification; the other mixture was used for quantifying the composition and the moisture content, which was used to calculate the dry mass basis weight. The dry mass basis weight of each component was then used to calculate the total organic carbon contents (TOC) and the total nitrogen contents (TN) using a previously established database, which had detailed statistics on the organic contents of each waste category. Methane yield potential $\left(L_{0}\right)$ and carbon sequestration factor (CSF) were selected as indicators for the biodegradability of waste. The values of $L_{0}$ and CSF were taken from a recent study on the biodegradability of organic waste in China. ${ }^{35}$ Data used here are listed in Table S2 of the Supporting Information.

2.3. GHG Efflux Quantification. The chamber method was applied to quantify the GHG effluxes. ${ }^{16-18}$ The diagram of the chamber is shown in Figure 2. The size of the chamber is 65 $\mathrm{cm} \times 65 \mathrm{~cm} \times 40 \mathrm{~cm}$ (length, width, and height). A garbage bin $(20 \mathrm{~cm} \times 20 \mathrm{~cm} \times 20 \mathrm{~cm})$ similar to the ones used in households is placed in the chamber. An electric fan is placed inside the chamber to mix the gases thoroughly. The fan is run during the gases sampling period in order to ensure the samples 


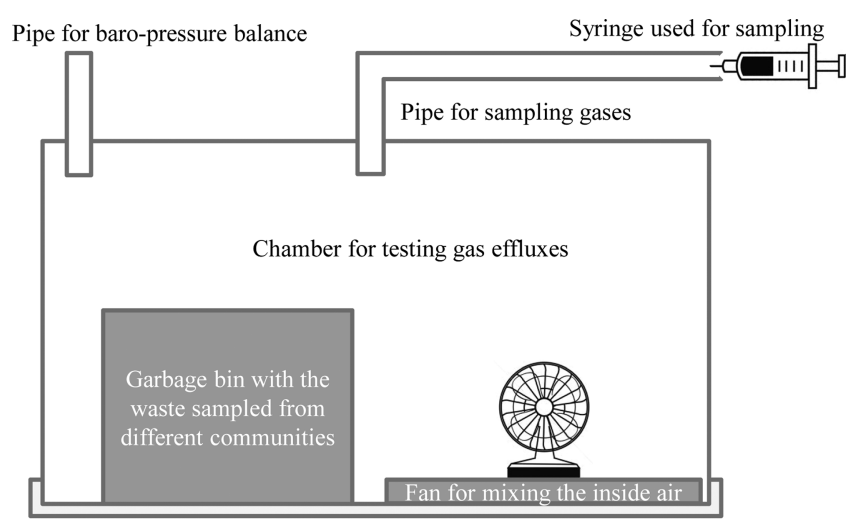

Chamber bottom with water seal

Figure 2. Diagram of chamber method.

were representative of the average gas mixture in the chamber. ${ }^{36-38}$ A base with water-filled grooves is used to seal the chamber in order to prevent leakage.

The rain-proofed chamber and simulated garbage bin (with waste collected from households) were placed outdoors for GHG emission monitoring. To simulate the length of the predisposal stage, each chamber experiment lasted for 2 days. The GHG effluxes were sampled in the following hours each day: 06:00-07:00, 10:00-11:00, 14:00-15:00, 18:00-19:00, and 22:00-23:00. Four samples were taken at 0,20,40, and 60 min in each of the hours, and an average GHG efflux was calculated and reported for that hour. In each sampling, $50 \mathrm{~mL}$ of air was drawn using a syringe, which was then split into $2 \mathrm{~mL}$ $\times 25 \mathrm{~mL}$ as technical duplicates. The ambient temperature was recorded during the monitoring, which varied from -12.4 to $35.8{ }^{\circ} \mathrm{C}$, with the seasonal average being $23.9,31.3,10.0$, and $-3.9^{\circ} \mathrm{C}$ for spring, summer, autumn, and winter, respectively.

The concentrations of $\mathrm{CO}_{2}, \mathrm{CH}_{4}$, and $\mathrm{N}_{2} \mathrm{O}$ of each sample were analyzed using gas chromatography (GC) (Agilent 7890A, U.S.A.) equipped with a flame ionized detector (FID) for $\mathrm{CO}_{2}$ and $\mathrm{CH}_{4}$ and electron capture detector $(\mu \mathrm{ECD})$ for $\mathrm{N}_{2} \mathrm{O}$.

The effluxes of $\mathrm{CO}_{2}, \mathrm{CH}_{4}$, and $\mathrm{N}_{2} \mathrm{O}$ were determined by eq 1.

$$
\begin{aligned}
F= & {\left[\rho_{0} \times 273 /(273+T) \times P / 0.1013\right.} \\
& \left.\times\left(H \times L \times W-H_{0} \times L_{0} \times W_{0}\right)\right] \times d_{c} / d_{t} \times \frac{10^{6}}{m}
\end{aligned}
$$

where $F$ is the GHG effluxes $\left(\mathrm{mg} \mathrm{kg}^{-1} \mathrm{~h}^{-1}\right)$; $\rho_{0}$ is the density of $\mathrm{CO}_{2}, \mathrm{CH}_{4}$, and $\mathrm{N}_{2} \mathrm{O}$ under the standard temperature and pressure (STP), $\rho_{\mathrm{CO} 2}$ is $1.977 \mathrm{~kg} \mathrm{~m}^{-3}, \rho_{\mathrm{CH} 4}$ is $0.717 \mathrm{~kg} \mathrm{~m}^{-3}$, $\rho_{\mathrm{N} 2 \mathrm{O}}$ is $2.982 \mathrm{~kg} \mathrm{~m}^{-3}$; $\mathrm{P}$ is barometric absolute pressure, MPa; $T$ is thermodynamic temperature $(\mathrm{K}) ; H, L$, and $W$ are the height, length, and width of the chamber, $0.4,0.65$, and $0.65 \mathrm{~m}$, respectively; $L_{0}$ and $W_{0}$ are the length and width of the garbage bin, 0.20 and $0.20 \mathrm{~m}$, respectively; $\mathrm{H}_{0}$ is the height of the waste placed in the garbage bin; $d c / d t$ is the increment rate of the $\mathrm{CO}_{2}, \mathrm{CH}_{4}$, and $\mathrm{N}_{2} \mathrm{O}$ concentrations $\left(\mathrm{ppm} \mathrm{h}^{-1}\right) ; m$ is the dry weight of the testing waste.

To compare the differences of GHG emission along the urban-rural gradient, the per capita GHG emissions were calculated for different communities using eq 2. $\mathrm{CO}_{2}$ emission was excluded according to the IPCC GHG inventory methodology. ${ }^{23}$

$$
\begin{aligned}
& \left.\mathrm{GHG}_{\text {Emission } j}\left(a \cdot F_{\mathrm{CH} 4 i j}+b \cdot F_{\mathrm{N} 2 \mathrm{O} i j}\right) \cdot 24 \cdot D \cdot W_{i j} \cdot\left(1-M_{i j}\right) / P_{j}\right) \\
& \quad=\frac{\sum_{i=1,2,3,4}}{4} \cdot 365
\end{aligned}
$$

where $\mathrm{GHG}_{\text {Emission }}$ is the per capita annual GHG emission of one community ( $\mathrm{g} \mathrm{CO}_{2}$ eq capita ${ }^{-1}$ year $^{-1}$ ); $F$ is the daily average efflux of $\mathrm{CH}_{4}$ and $\mathrm{N}_{2} \mathrm{O}\left(\mathrm{g} \mathrm{kg}^{-1} \mathrm{~h}^{-1}\right) ; W$ is the total weight of the food waste collected from each community; $M$ is the moisture content of the collected food waste from each community; $P$ is the total number of residents covered by our waste sampling in each community; $a$ and $b$ are $\mathrm{GWP}_{100}$ of $\mathrm{CH}_{4}$ and $\mathrm{N}_{2} \mathrm{O}, 25$ and 298 respectively; ${ }^{3} \mathrm{D}$ is the length of the predisposal stage ( $D=2$ in this work); $i$ designates the four seasons; $j$ is the five communities studied.

2.4. Statistical Analysis. SPSS 16.0 was used for the statistical analysis. One-way ANOVA was used to analyze whether there are statistically significant differences in the GHG effluxes in different seasons. Spearman's correlation test (2-tail) was used to analyze the monotonic correlation between GHG effluxes and potentially influential factors, including ambient temperature, moisture, TOC, TN, C:N ratio, $L_{0}$, and CSF. Regression analysis was done for GHG effluxes and temperature given the strong spearman correlation coefficient. Adjusted $R^{2}$ and the Akaike information criterion for small sample size (AICc) were used for model comparison.

\section{RESULTS AND DISCUSSION}

\subsection{Annual Total GHG Emissions in the Predisposal} Stage. The annual average $\mathrm{CO}_{2}, \mathrm{CH}_{4}$, and $\mathrm{N}_{2} \mathrm{O}$ effluxes in the predisposal stage were $(1.6 \pm 0.9) 10^{3}, 0.049 \pm 0.016$, and 0.94 $\pm 0.54 \mathrm{mg} \mathrm{kg}^{-1} \mathrm{~h}^{-1}$ (dry matter basis), respectively, in the five communities in Beijing. After excluding $\mathrm{CO}_{2}$ from the GHG accounting due to assuming carbon neutrality in biogenic waste,

\begin{tabular}{|c|c|c|c|c|c|}
\hline \multirow[b]{2}{*}{ stages } & \multirow[b]{2}{*}{ source } & \multirow[b]{2}{*}{ MC (\%) } & \multicolumn{3}{|c|}{ GHG effluxes $\left(\mathrm{mg} \mathrm{kg}(\mathrm{dm})^{-1} \mathrm{~h}^{-1}\right)$} \\
\hline & & & $\mathrm{CO}_{2}$ & $\mathrm{CH}_{4}$ & $\mathrm{~N}_{2} \mathrm{O}$ \\
\hline predisposal & this work & $73.7-82.1$ & $(1.6 \pm 0.9) 10^{3}$ & $0.049 \pm 0.016$ & $0.94 \pm 0.54$ \\
\hline \multirow[t]{3}{*}{ home composting } & Andersen et al., $2010^{17, a}$ & $63.8-78.9$ & $39-42^{d}$ & $0.09-0.13^{d}$ & $0.07^{d}$ \\
\hline & Martínez-Blanco et al., $2010^{18}$ & 43.6 & $\mathrm{n} / \mathrm{a}$ & $0.12^{d}$ & $0.50^{d}$ \\
\hline & Adhikari et al., $2013^{20, b}$ & 75.9 & $31^{d}$ & $\mathrm{n} / \mathrm{d}$ & $0.22^{d}$ \\
\hline full-scale composting & Colón et al., $2012^{19}$ & $\mathrm{n} / \mathrm{a}$ & $\mathrm{n} / \mathrm{a}$ & $0.34-4.37$ & $0.035-0.251$ \\
\hline landfill & Rinne et al., $2005^{39}$ & $\mathrm{n} / \mathrm{a}$ & $5640^{c}$ & $1660^{c}$ & $4.2^{c}$ \\
\hline
\end{tabular}
the annual per capita GHG emission in the predisposal stage was $240 \pm 140 \mathrm{~g} \mathrm{CO}_{2}$ eq capita ${ }^{-1}$ year $^{-1}$ and was predominantly

Table 1. Comparison of GHG Effluxes from Predisposal Stage and Other MSW Facilities

${ }^{a}$ No mixing experimental group. ${ }^{b}$ Plastic bin experimental group. ${ }^{c}$ Unit is $\mathrm{mg} \mathrm{m}{ }^{-2} \mathrm{~h}^{-1}$. ${ }^{d}$ Calculated based on the original data, moisture contents, and composting duration days; $\mathrm{n} / \mathrm{d}-$ not detected; $\mathrm{n} / \mathrm{a}-$ not applicable. 

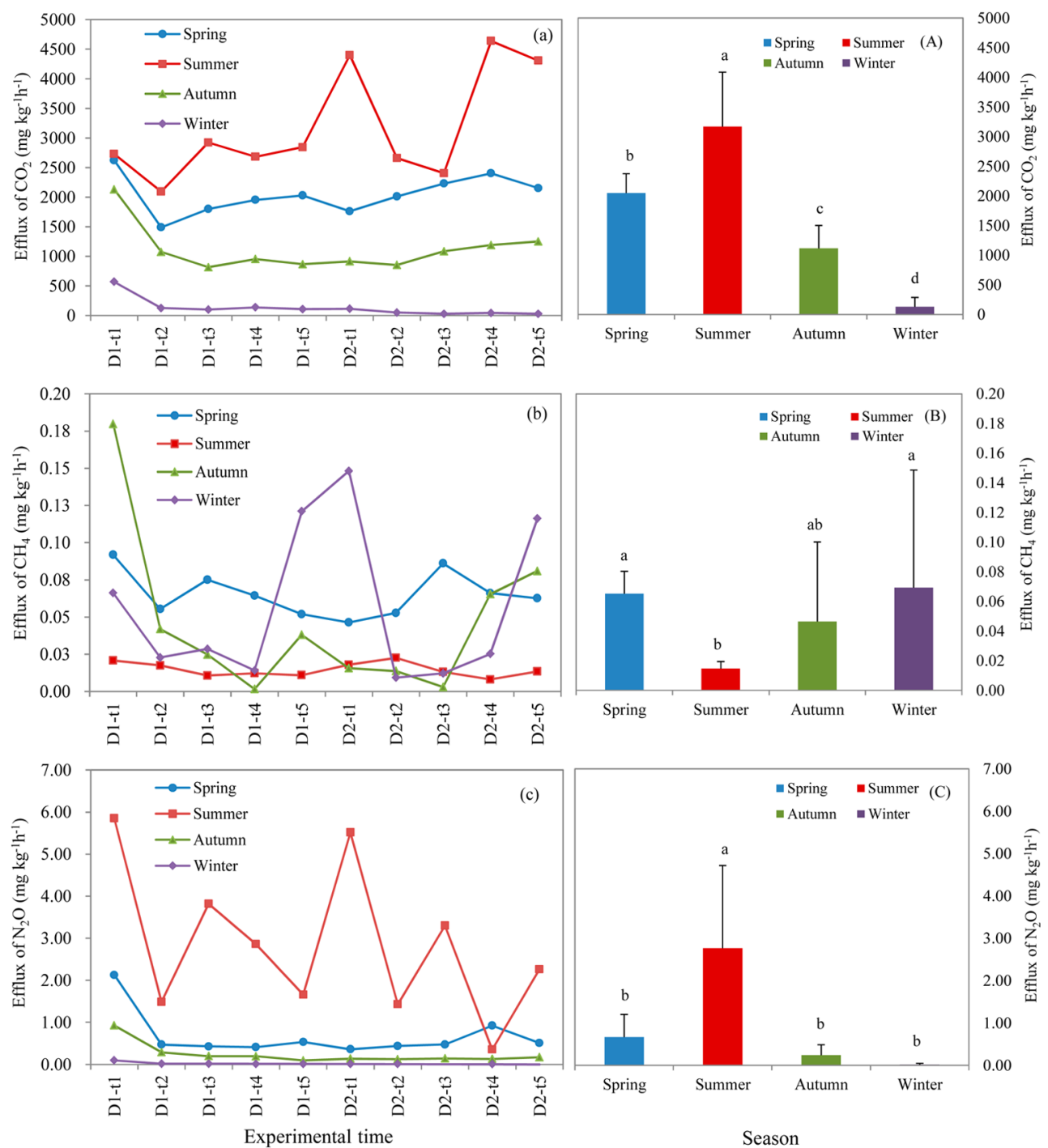

Figure 3. Seasonal GHG effluxes of municipal solid waste by chamber experiments. Panels (a), (b), and (c) are the community average $\mathrm{CO}_{2}, \mathrm{CH}_{4}$ and $\mathrm{N}_{2} \mathrm{O}$ effluxes in each testing time during two experimental days. D1 and D2 are the first and second day of the experiment. $t$ is the testing time in each day: $\mathrm{t} 1$ (06:00-07:00), $\mathrm{t} 2$ (10:00-11:00), t3 (14:00-15:00), t4 (18:00-19:00) and t5 (22:00-23:00). Panels (A), (B), and (C) are community-average seasonal $\mathrm{CO}_{2}, \mathrm{CH}_{4}$, and $\mathrm{N}_{2} \mathrm{O}$ effluxes. Error bar indicates the data obtained from different communities; symbols a-d indicate statistical significance $(p<0.05)$.

$\mathrm{N}_{2} \mathrm{O}$ emission (0.81 $\mathrm{g} \mathrm{N}_{2} \mathrm{O}$ capita $^{-1}$ year $^{-1}$ or $240 \mathrm{~g} \mathrm{CO}_{2}$ eq capita $^{-1}$ year $\left.^{-1}\right)$. There are two other interesting features. First, the $\mathrm{CO}_{2}$ and $\mathrm{N}_{2} \mathrm{O}$ effluxes in the predisposal stage measured in this study are higher than the effluxes reported for home composting and full-scale composting. For example, hourly $\mathrm{CO}_{2}$ and $\mathrm{N}_{2} \mathrm{O}$ efflux in the predisposal stage are 38-52 times and 2-13 times larger than corresponding fluxes in home composting (Table 1). Second, the $\mathrm{N}_{2} \mathrm{O}$ efflux was much larger than $\mathrm{CH}_{4}$ in the predisposal stage, which was very different from landfills but somewhat similar to composting. The percentages of $\mathrm{CO}_{2}, \mathrm{CH}_{4}$, and $\mathrm{N}_{2} \mathrm{O}$ in the predisposal stage were $85.40 \pm 7.15 \%, 0.06 \pm 0.60 \%$, and $14.54 \pm 7.49 \%$, respectively, on a $\mathrm{CO}_{2}$ eq basis.

Our findings are somewhat supported by mechanism studies. For instance, the methane emissions are facilitated by low oxygen conditions and the lag-phase time of $\mathrm{CH}_{4}$ yield $(5-25$ days), ${ }^{30,35,40}$ which is not available in the simulated predisposal stage. In contrast, $\mathrm{N}_{2} \mathrm{O}$ emission is a consequence of the richness in nitrogen and frequently alternating aerobic and anaerobic conditions ${ }^{41}$ and is possibly more intense in the first
3 days, $^{42}$ which is similar to the conditions in the predisposal stage. The overall larger GHG effluxes from the predisposal stage may be related to the short duration of the monitoring. When monitored over periods from 2 months to 2 years, GHG effluxes from home and full-scale composting have been shown to decline overtime. ${ }^{17-22}$

3.2. Seasonal GHG Emissions in the Predisposal Stage. Different GHG showed different seasonal trends. Seasonal $\mathrm{CO}_{2}$ effluxes varied from $0.13 \pm 0.16$ to $(3.2 \pm$ $0.9) 10^{3} \mathrm{mg} \mathrm{kg}^{-1} \mathrm{~h}^{-1}$ and showed statistically significant differences in each season (summer $>$ spring $>$ autumn $>$ winter, $p<0.05)$. The $\mathrm{CO}_{2}$ efflux in the summer was 24-fold over that in the winter (Figure 3(a), (A)). In addition, the $\mathrm{CO}_{2}$ effluxes slightly increased during the 2 days of monitoring in the spring, summer, and autumn (Figure 3(a)). The seasonal $\mathrm{N}_{2} \mathrm{O}$ effluxes had a similar trend as $\mathrm{CO}_{2}$, which varied from $0.017 \pm 0.028$ to $2.8 \pm 2.0 \mathrm{mg} \mathrm{kg}(\mathrm{dm})^{-1} \mathrm{~h}^{-1}$, with the summer about 159 times as high as the winter (Figure 3(c), (C)).

In contrast, the $\mathrm{CH}_{4}$ efflux in summer was significantly lower than that in spring and winter and did not show significant 
Table 2. Spearman Correlations Coefficient of GHGs Effluxes and Influential Factors

\begin{tabular}{|c|c|c|c|c|}
\hline factors & Spearman correlation & efflux $\mathrm{CO}_{2}$ & efflux $\mathrm{CH}_{4}$ & efflux $\mathrm{N}_{2} \mathrm{O}$ \\
\hline \multirow[t]{2}{*}{ temperature } & correlation coefficient & $0.944^{a}$ & -0.209 & $0.890^{a}$ \\
\hline & sig. (2-tailed) & 0.000 & 0.376 & 0.000 \\
\hline \multirow[t]{2}{*}{ TOC } & correlation coefficient & -0.284 & 0.158 & -0.377 \\
\hline & sig. (2-tailed) & 0.225 & 0.506 & 0.101 \\
\hline \multirow[t]{2}{*}{$\mathrm{TN}$} & correlation coefficient & -0.063 & -0.214 & -0.126 \\
\hline & sig. (2-tailed) & 0.791 & 0.366 & 0.596 \\
\hline \multirow[t]{2}{*}{$\mathrm{C}: \mathrm{N}$ ratio } & correlation coefficient & -0.176 & $0.502^{b}$ & -0.233 \\
\hline & sig. (2-tailed) & 0.458 & 0.024 & 0.323 \\
\hline \multirow[t]{2}{*}{ moisture } & correlation coefficient & -0.155 & -0.024 & -0.111 \\
\hline & sig. (2-tailed) & 0.514 & 0.920 & 0.640 \\
\hline \multirow[t]{2}{*}{ methane yield potential $\left(L_{0}\right)$} & correlation coefficient & -0.277 & -0.006 & -0.361 \\
\hline & sig. (2-tailed) & 0.238 & 0.980 & 0.118 \\
\hline \multirow[t]{2}{*}{ carbon sequestration factor (CSF) } & correlation coefficient & -0.030 & -0.039 & 0.12 \\
\hline & sig. (2-tailed) & 0.900 & 0.870 & 0.960 \\
\hline
\end{tabular}

${ }^{a}$ Correlation is significant at the 0.01 level. ${ }^{b}$ Correlation is significant at the 0.05 level; daily average data, $n=20$.

seasonal differences in spring, autumn, and winter. The seasonal $\mathrm{CH}_{4}$ effluxes in spring, summer, autumn, and winter were 0.065 $\pm 0.015,0.014 \pm 0.005,0.046 \pm 0.054$, and $0.069 \pm 0.079 \mathrm{mg}$ $\mathrm{kg}^{-1} \mathrm{~h}^{-1}$, respectively (Figure 3(b), (B)). Our $\mathrm{CH}_{4}$ emissions results are similar to the insignificant seasonal trends of landfill methane effluxes, which were considered to be related to landfill operation, meteorological conditions, and ground temperature. $^{16,43}$

3.3. Factors Affecting GHG emissions. Spearman correlation analysis suggests that $\mathrm{CO}_{2}$ and $\mathrm{N}_{2} \mathrm{O}$ effluxes significantly increase as the ambient temperature increases $(p$ $<0.01$ ), while the correlation between $\mathrm{CH}_{4}$ effluxes and the ambient temperature is not significant (Table 2). In addition, the $\mathrm{CH}_{4}$ effluxes show a moderately significant correlation with the C:N ratio $(p<0.05)$. Other factors, namely TOC, TN, moisture content, methane yield potential $\left(L_{0}\right)$, and carbon sequestration factor (CSF) are not significantly correlated with the GHG emissions, although they have been found to affect the GHG emissions to some extent in organic waste composting and anaerobic digestion. ${ }^{35,44}$

The correlations between temperature and $\mathrm{CO}_{2} / \mathrm{N}_{2} \mathrm{O}$ effluxes are presented in Figure 4. For $\mathrm{CO}_{2}$, both the linear and exponential models were a good fit based on the adjusted $R^{2}$ (linear: adjusted $R^{2}=0.86$; exponential: adjusted $R^{2}=0.82$ ). However, AICc suggested that the exponential model was potentially a preferred model given its low AICc value (Table S3. Supporting Information). For $\mathrm{N}_{2} \mathrm{O}$, the exponential model had a lower AICc than the linear model and a higher adjusted $R^{2}$ (linear: adjusted $R^{2}=0.33$ and $\mathrm{AICc}=74.7$; exponential: adjusted $R^{2}=0.48$ and $\left.\mathrm{AICc}=102.0\right)$. Additional information on the curve fitting is shown in Table S3 of the Supporting Information.

Temperature is vital to microbial activity ${ }^{45,46}$ and potentially a key driver of GHG emissions in the predisposal stage. Strong correlations between $\mathrm{CO}_{2} / \mathrm{N}_{2} \mathrm{O}$ effluxes and ambient temperature were found in the studies of MSW landfill and composting gases. ${ }^{31,44}$ Our study generally agrees with previous findings and suggests that $\mathrm{CO}_{2} / \mathrm{N}_{2} \mathrm{O}$ effluxes could both increase exponentially when temperature exceeds $25{ }^{\circ} \mathrm{C}$. In composting studies, microbial activity could be impeded when the environmental temperature increases to $50{ }^{\circ} \mathrm{C}$. ${ }^{32}$ However, the ambient temperature around garbage bins seldom reaches $50{ }^{\circ} \mathrm{C}$ in the predisposal stage.
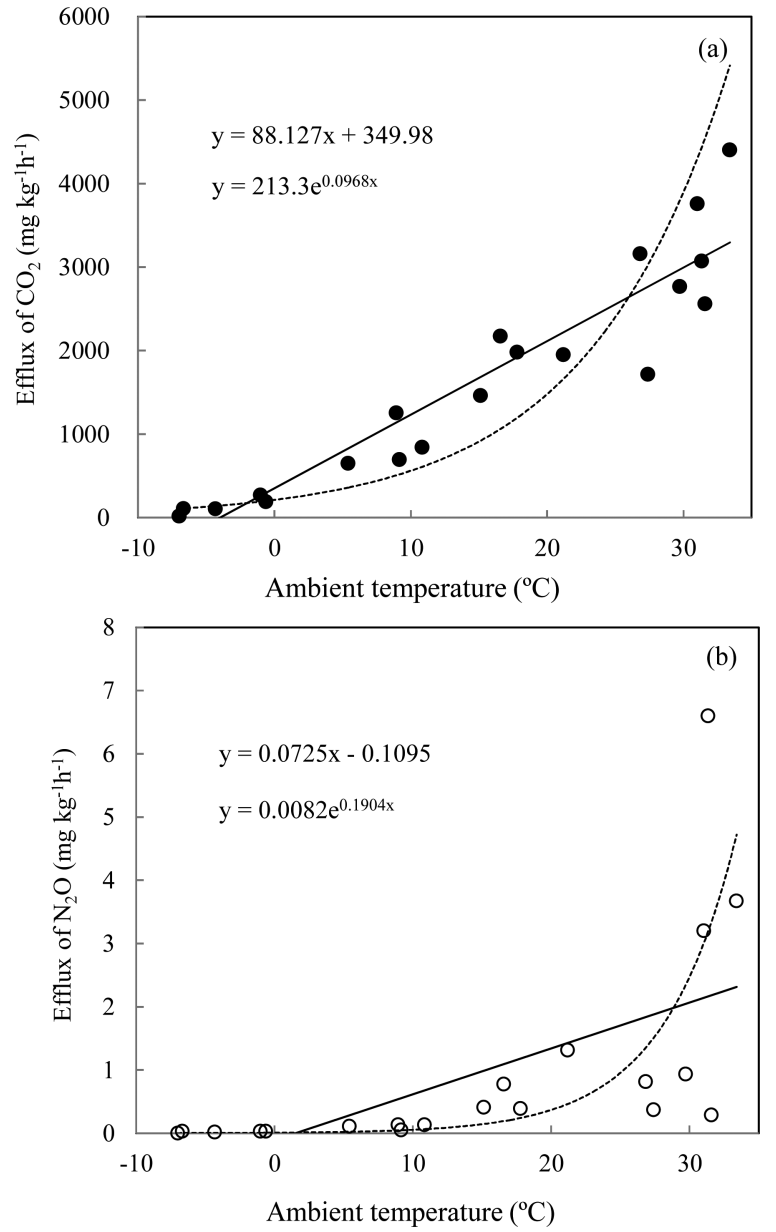

Figure 4. Linear and exponential regression of ambient temperatures and $\mathrm{CO}_{2} / \mathrm{N}_{2} \mathrm{O}$ effluxes. (a) $\mathrm{CO}_{2}$ efflux and temperature; (b) $\mathrm{N}_{2} \mathrm{O}$ efflux and temperature.

Some other factors not analyzed in this research could also contribute to the GHG effluxes in the predisposal stage. In this study, organic fractions were separated from other household waste for more reliable characterization. However, source separation is not done meticulously by every household, the GHG emission rate and composition may change when the organic fractions are mixed with other types of waste due to 
changes in moisture content and interstitial oxygen concentration. ${ }^{46}$ Furthermore, other gas effluxes, for example, volatile organic compounds, carbon monoxide, and ammonia, could also have global warming impacts or affect the $\mathrm{CH}_{4}$ and $\mathrm{N}_{2} \mathrm{O}$ effluxes. Further studies on the physio-chemical and biological factors are needed to elucidate the mechanism of the GHG emissions from the MSW predisposal stage.

3.4. GHG Emissions in Different Communities. While still inconclusive, our results suggest that GHG emissions from MSW in the predisposal stage may have community-tocommunity differences which may be related to demographics, average income, and different eating habits. For example, the GHG emissions from the MSW predisposal stage decreased as we moved from urban to rural areas (Figure 5). The total GHG

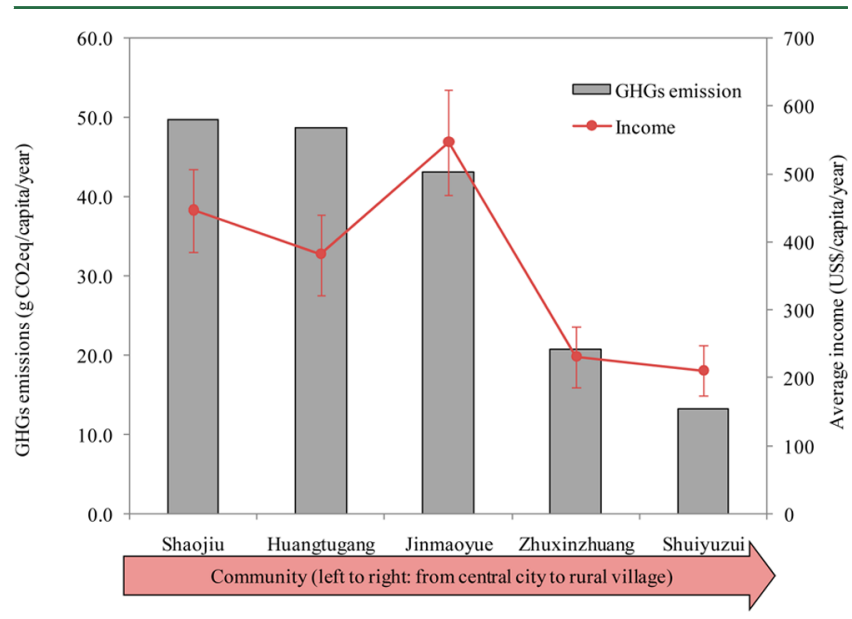

Figure 5. Per capita GHG emissions and income of different communities in this study.

emissions from Shaojiu (inner city) were $50 \mathrm{~g} \mathrm{CO}_{2} \mathrm{eq} \mathrm{capita}^{-1}$ year $^{-1}$, which was 3.8- and 2.4-fold higher than the emissions from suburb and rural communities. The households in Shaojiu and Huangtugang also produced twice as much as food wastes as other communities ( 0.342 and $0.305 \mathrm{~kg}_{\text {capita }}{ }^{-1}$ day $^{-1}$ respectively). Our results are consistent with a previous study, which suggested that food waste generation may be related to average income and family size. ${ }^{47}$

\section{DISCUSSION}

4.1. Significance to GHG Emission Accounting in the Waste Sector. Our study finds, for the first time, that the predisposal stage of MSW management has nontrivial biogenic $\mathrm{N}_{2} \mathrm{O}$ emissions. It estimates that the $\mathrm{N}_{2} \mathrm{O}$ emission in the MSW predisposal stage was $0.81 \mathrm{~g} \mathrm{capita}^{-1}$ year $^{-1}$ in Beijing. To put this intensity in the context of Beijing, annual total $\mathrm{N}_{2} \mathrm{O}$ emission from MSW predisposal stage is $5 \mathrm{Gg} \mathrm{CO}_{2} \mathrm{eq}^{-1}$, which amounts to $20 \%$ of that in the disposal stage in Beijing (Table 3). In addition, the per capita $\mathrm{N}_{2} \mathrm{O}$ emission estimated by this study is most likely an underestimate for two reasons. First, the length of the predisposal stage is often 3 times longer in many other cities than that in Beijing (2 days). ${ }^{28-30}$ Second, only MSW from households was included in this study, which is only a portion of the total food waste produced per person. For high-income households, the food waste produced in cafeterias or restaurants could be substantial. ${ }^{48}$

Furthermore, the $\mathrm{N}_{2} \mathrm{O}$ emission was significant, while the $\mathrm{CH}_{4}$ emission was insignificant in the predisposal stage, which is similar to the GHG profile in composting but very different from that in landfills. ${ }^{39}$ This calls attention to a better understanding of the biochemical mechanism of $\mathrm{N}_{2} \mathrm{O}$ generation. $\mathrm{N}_{2} \mathrm{O}$ emissions from landfills in Beijing were not reported in the current literature, and the model for estimating $\mathrm{N}_{2} \mathrm{O}$ in landfills was not included in the IPCC inventory. ${ }^{23}$ Therefore, a comparison is unavailable for the $\mathrm{N}_{2} \mathrm{O}$ emissions from the predisposal stage and landfills. As a preliminary comparison, if $4.2 \mathrm{mg} \mathrm{N}_{2} \mathrm{O} \mathrm{m}^{-2} \mathrm{~h}^{-1}$ is applied as suggested by ref 39 , the hourly $\mathrm{N}_{2} \mathrm{O}$ efflux will be $0.84 \times 10^{-3} \mathrm{mg} \mathrm{kg}^{-1} \mathrm{~h}^{-1}$, $0.1 \%$ of that in the predisposal stage, for a landfill with a depth of $5 \mathrm{~m}$ and a density of 1 ton $\mathrm{m}^{-3}$. However, it should be pointed out that the total GHG emission from landfills is still dominant in the entire life cycle of MSW management despite our findings.

4.2. Significance to the Urban Carbon Cycle. Carbon management, particularly capturing the energy contained in waste organic carbon, is an emerging issue in the field of biogeochemical cycles in an urban ecosystem. ${ }^{49,50}$ Estimates of the energy potential and policy recommendations are often based on the estimate of carbon flows in organic waste. ${ }^{51}$ In this research, we find that annually the loss of carbon in the predisposal stage is up to $5 \%$ of the TOC contents of food waste, and the loss can reach $10 \%$ in the summer. It indicates that the assessments of renewable energy potential from MSW may need to be refined to account for the loss of carbon in the predisposal stage.

Besides, there are potential community-to-community differences in the GHG emissions and carbon flows of MSW management. Our work suggests that communities in the central city with middle income and small family sizes may produce more GHG emissions than suburban communities and rural villages. The differences in waste generation and GHG emissions among communities should be considered when designing policies to improve the carbon management in cities. Related studies should also consider such community-tocommunity differences at a higher resolution for more refined understandings.

4.3. Policy Implications. GHG emissions has become an increasingly popular indicator to gauge the sustainability of

Table 3. Estimation of GHG Emissions from Predisposal and Disposal of Municipal Solid Waste in Beijing, 2013

\begin{tabular}{lccccc}
\multicolumn{1}{c}{ stages } & quantity of MSW (million ton $\left.\mathrm{yr}^{-1}\right)$ & $\mathrm{N}_{2} \mathrm{O}$ emission $\left(\mathrm{Gg} \mathrm{CO}_{2} \mathrm{eq} \mathrm{yr}^{-1}\right)$ & percentage (\%) & total GHG emission $\left(\mathrm{Gg} \mathrm{CO}_{2} \mathrm{eq} \mathrm{yr}^{-1}\right)$ & $\mathrm{percentage}^{(\%)}$ \\
predisposal & 6.67 & $5^{a}$ & 20 & $5^{a}$ & 0.3 \\
compost & 0.79 & 7 & 26 & 14 & 350 \\
incineration & 0.98 & 14 & 54 & 1781 & 16 \\
landfill & 4.9 & $\mathrm{n} / \mathrm{a}^{b}$ & 0 & 2150 & 83 \\
total & 6.67 & 26 & 100 & 100
\end{tabular}

${ }^{a} \mathrm{~N}_{2} \mathrm{O}$ emission from predisposal stage is calculated by per capita $\mathrm{N}_{2} \mathrm{O}$ emission $\left(0.81 \mathrm{~g} \mathrm{~N}_{2} \mathrm{O}\right.$ capita ${ }^{-1} \mathrm{yr}^{-1}$ in this work $)$ and the population of Beijing in 2013 (21 million). ${ }^{b}$ Not applicable by IPCC inventory. ${ }^{23}$ GHG emission data of compost, incineration, and landfill are taken from ref 33. 
MSW management. ${ }^{5-7}$ Our study suggests that the predisposal stage should be taken into account when assessing the GHG impact of MSW management. Systemic efforts are needed to quantify GHG emissions in this stage and build it into the system design. Furthermore, our study suggests that increasing the MSW clearance frequency in the summer can potentially achieve the dual purpose of reducing the GHG emissions and conserving organic carbon resources for bioenergy recovery. Cost-effective measures to reduce the temperature in garbage bins are also beneficial to reduce the GHG emissions, carbon loss, and odor (as a co-benefit) in the predisposal stage, for example, choosing the location of MSW storage more carefully to avoid direct sunlight and/or changing the color or the material of garbage bins to reduce heat absorption.

\section{ASSOCIATED CONTENT}

\section{S Supporting Information}

The Supporting Information is available free of charge on the ACS Publications website at DOI: 10.1021/acs.est.6b05180.

Table S1: Detail information on studied communities, Beijing. Table S2: Previously established database on the characteristics of different category of food wastes. Table S3: Curve fits and their statistics between $\mathrm{CO}_{2}$ effluxes and temperatures and $\mathrm{N}_{2} \mathrm{O}$ effluxes and temperatures. (PDF)

\section{AUTHOR INFORMATION}

\section{Corresponding Author}

*Phone: +86 10 62849147. E-mail: cbzhou@rcees.ac.cn.

ORCID ${ }^{\circ}$

\section{Chuanbin Zhou: 0000-0001-7166-9682}

\section{Author Contributions}

The manuscript was written through contributions of all authors. All authors have given approval to the final version of the manuscript.

\section{Notes}

The authors declare no competing financial interest.

\section{ACKNOWLEDGMENTS}

This project is supported by the National Natural Science Foundation of China $(41201579,71533004)$ and the China National Major Science and Technology Program for Water Pollution Control and Treatment (2014ZX07201). The authors thank the residents in the study cites for their help during this research. The authors are also grateful to Dr. Benjamin Sprecher for helpful discussions.

\section{REFERENCES}

(1) Powell, J. T.; Townsend, T. G.; Zimmerman, J. B. Estimates of solid waste disposal rates and reduction targets for landfill gas emissions. Nat. Clim. Change 2015, 6 (2), 162-165.

(2) Inventory of U.S. Greenhouse Gas Emissions and Sinks: 1990-2014; United States Environmental Protection Agency: Washington, DC, 2016.

(3) Climate Change 2014: Mitigation of Climate Change; Intergovernmental Panel on Climate Change: Geneva, Switzerland, 2014.

(4) Second National Communication on Climate Change of The People's Republic of China. 2012. http://unfccc.int/essential background/library/items/3599.php?rec=j\&priref=7666\#beg $\quad($ accessed December 12, 2016).

(5) Couth, R.; Trois, C. Sustainable waste management in Africa through CDM projects. Waste Manage. 2012, 32 (11), 2115-2125.
(6) Chen, Y.; Lo, S. Evaluation of greenhouse gas emissions for several municipal solid waste management strategies. J. Cleaner Prod. 2016, 113, 606-612.

(7) Mühle, S.; Balsam, I.; Cheeseman, C. Comparison of carbon emissions associated with municipal solid waste management in Germany and the UK. Resour., Conserv. Recycl. 2010, 54 (11), 793801.

(8) Wang, Z.; Geng, L. Carbon emissions calculation from municipal solid waste and the influencing factors analysis in China. J. Cleaner Prod. 2015, 104, 177-184.

(9) Zhao, W.; Van der Voet, E.; Zhang, Y.; Huppes, G. Life cycle assessment of municipal solid waste management with regard to greenhouse gas emissions: case study of Tianjin, China. Sci. Total Environ. 2009, 407 (5), 1517-1526.

(10) Mohareb, A. K.; Warith, M. A.; Diaz, R. Modelling greenhouse gas emissions for municipal solid waste management strategies in Ottawa, Ontario, Canada. Resour., Conserv. Recycl. 2008, 52 (11), $1241-1251$

(11) Woon, K. S.; Lo, I. M. Greenhouse gas accounting of the proposed landfill extension and advanced incineration facility for municipal solid waste management in Hong Kong. Sci. Total Environ. 2013, 458-460, 499-507.

(12) Chen, T. C.; Lin, C. F. Greenhouse gases emissions from waste management practices using Life Cycle Inventory model. J. Hazard. Mater. 2008, 155 (1), 23-31.

(13) Kumar, S.; Mondal, A.; Gaikwad, S.; Devotta, S.; Singh, R Qualitative assessment of methane emission inventory from municipal solid waste disposal sites: a case study. Atmos. Environ. 2004, 38 (29), 4921-4929.

(14) Amini, H. R; Reinhart, D. R.; Niskanen, A. Comparison of firstorder-decay modeled and actual field measured municipal solid waste landfill methane data. Waste Manage. 2013, 33 (12), 2720-2728.

(15) Abushammala, M. F.; Basri, N. E. A.; Younes, M. K. Seasonal variation of landfill methane and carbon dioxide emissions in a tropical climate. Int. J. Environ. Sci. Dev. 2016, 7 (8), 586.

(16) BÖrjesson, G.; Danielsson, Å.; Svensson, B. H. Methane fluxes from a Swedish landfill determined by geostatistical treatment of static chamber measurements. Environ. Sci. Technol. 2000, 34 (18), 40444050.

(17) Andersen, J. K.; Boldrin, A.; Christensen, T. H.; Scheutz, C. Greenhouse gas emissions from home composting of organic household waste. Waste Manage. 2010, 30 (12), 2475-2482.

(18) Martínez-Blanco, J.; Colón, J.; Gabarrell, X.; Font, X.; Sánchez, A.; Artola, A.; Rieradevall, J. The use of life cycle assessment for the comparison of biowaste composting at home and full scale. Waste Manage. 2010, 30 (6), 983-994.

(19) Colón, J.; Cadena, E.; Pognani, M.; Barrena, R.; Sánchez, A.; Font, X.; Artola, A. Determination of the energy and environmental burdens associated with the biological treatment of source-separated municipal solid wastes. Energy Environ. Sci. 2012, 5 (2), 5731-5741.

(20) Adhikari, B. K.; Trémier, A.; Barrington, S.; Martinez, J.; Daumoin, M. Gas emissions as influenced by home composting system configuration. J. Environ. Manage. 2013, 116, 163-171.

(21) Ermolaev, E.; Sundberg, C.; Pell, M.; Jönsson, H. Greenhouse gas emissions from home composting in practice. Bioresour. Technol. 2014, 151, 174-182.

(22) Sánchez, A.; Artola, A.; Font, X.; Gea, T.; Barrena, R.; Gabriel, D.; Sánchez-Monedero, M. Á.; Roig, A.; Cayuela, M. L.; Mondini, C. Greenhouse gas emissions from organic waste composting. Environ. Chem. Lett. 2015, 13 (3), 223-238.

(23) 2006 IPCC Guidelines for National Greenhouse Gas Inventories. Intergovernmental Panel on Climate Change: Geneva, Switzerland, 2006. http://www.ipcc-nggip.iges.or.jp/public/2006gl/ vol5.html (accessed December 12, 2016).

(24) Bastin, L.; Longden, D. M. Comparing transport emissions and impacts for energy recovery from domestic waste (EfW): Centralised and distributed disposal options for two UK Counties. Comput. Environ. Urban. 2009, 33 (6), 492-503. 
(25) Calabro, P. S. Greenhouse gases emission from municipal waste management: the role of separate collection. Waste Manage. 2009, 29 (7), 2178-2187.

(26) McDougall, F. R.; White, P. R.; Franke, M.; Hindle, P. Integrated Solid Waste Management: A Life Cycle Inventory; John Wiley \& Sons: New York, 2008.

(27) Zhang, D. Q.; Tan, S. K.; Gersberg, R. M. Municipal solid waste management in China: status, problems and challenges. J. Environ. Manage. 2010, 91 (8), 1623-1633.

(28) Yepsen, R. Residential food waste collection in the US. BioCycle 2012, 53 (1), 23.

(29) State of Composting in the US: What, Why, Where \& How. Institute for Local Self-Reliance: Minneapolis, MN, 2014. https://ilsr. org/state-of-composting (accessed December 12, 2016).

(30) Tchobanoglous, G.; Theisen, H.; Vigil, S. Integrated Solid Waste Management: Engineering Principles and Management Issues; McGrawHill, Inc.: New York, 1993.

(31) Haruta, S.; Nakayama, T.; Nakamura, K.; Hemmi, H.; Ishii, M.; Igarashi, Y.; Nishino, T. Microbial diversity in biodegradation and reutilization processes of garbage. J. Biosci. Bioeng. 2005, 99 (1), 1-11.

(32) Hassen, A.; Belguith, K.; Jedidi, N.; Cherif, A.; Cherif, M.; Boudabous, A. Microbial characterization during composting of municipal solid waste. Bioresour. Technol. 2001, 80 (3), 217-225.

(33) Yu, Y.; Zhang, W. Greenhouse gas emissions from solid waste in Beijing: The rising trend and the mitigation effects by management improvements. Waste Manage. Res. 2016, 34 (4), 368-377.

(34) Wang, H.; Wang, C. Municipal solid waste management in Beijing: characteristics and challenges. Waste Manage. Res. 2013, 31 (1), 67-72.

(35) Zheng, W.; Phoungthong, K.; Lü, F.; Shao, L. M.; He, P. J. Evaluation of a classification method for biodegradable solid wastes using anaerobic degradation parameters. Waste Manage. 2013, 33 (12), 2632-2640.

(36) Kroon, P. S.; Hensen, A.; Van den Bulk, W. C. M.; Jongejan, P. A. C; Vermeulen, A. T. The importance of reducing the systematic error due to non-linearity in $\mathrm{N}_{2} \mathrm{O}$ flux measurements by static chambers. Nutr. Cycling Agroecosyst. 2008, 82 (2), 175-186.

(37) Christiansen, J. R.; Korhonen, J. F.; Juszczak, R.; Giebels, M.; Pihlatie, M. Assessing the effects of chamber placement, manual sampling and headspace mixing on $\mathrm{CH}_{4}$ fluxes in a laboratory experiment. Plant Soil 2011, 343 (1-2), 171-85.

(38) Pihlatie, M. K.; Christiansen, J. R.; Aaltonen, H.; Korhonen, J. F.; Nordbo, A.; Rasilo, T.; Benanti, G.; Giebels, M.; Helmy, M.; Sheehy, J.; Jones, S.; et al. Comparison of static chambers to measure $\mathrm{CH}_{4}$ emissions from soils. Agric. For. Meteorol. 2013, 171-172, 124136.

(39) Rinne, J.; Pihlatie, M.; Lohila, A.; Thum, T.; Aurela, M.; Tuovinen, J. P.; Laurila, T.; Vesala, T. Nitrous oxide emissions from a municipal landfill. Environ. Sci. Technol. 2005, 39 (20), 7790-7793.

(40) Zhang, R.; El-Mashad, H. M.; Hartman, K.; Wang, F.; Liu, G.; Choate, C.; Gamble, P. Characterization of food waste as feedstock for anaerobic digestion. Bioresour. Technol. 2007, 98 (4), 929-935.

(41) Kampschreur, M. J.; Temmink, H.; Kleerebezem, R.; Jetten, M. S.; van Loosdrecht, M. C. Nitrous oxide emission during wastewater treatment. Water Res. 2009, 43 (17), 4093-4103.

(42) El Kader, N. A.; Robin, P.; Paillat, J. M.; Leterme, P. Turning, compacting and the addition of water as factors affecting gaseous emissions in farm manure composting. Bioresour. Technol. 2007, 98 (14), 2619-2628.

(43) Ishigaki, T.; Yamada, M.; Nagamori, M.; Ono, Y.; Inoue, Y. Estimation of methane emission from whole waste landfill site using correlation between flux and ground temperature. Environ. Geol. 2005, 48 (7), 845-853.

(44) Jiang, T.; Schuchardt, F.; Li, G.; Guo, R.; Zhao, Y. Effect of C/N ratio, aeration rate and moisture content on ammonia and greenhouse gas emission during the composting. J. Environ. Sci. 2011, 23 (10), $1754-1760$.

(45) Sundh, I.; Rönn, S. Microbial succession during composting of source-separated urban organic household waste under different initial temperature conditions. In Microbiology of Composting; Insam, H., Riddech, N., Klammer, S., Eds.; Springer: Berlin, 2002; pp 53-64.

(46) Strom, P. F. Effect of temperature on bacterial species diversity in thermophilic solid-waste composting. Appl. Environ. Microbiol. 1985, 50 (4), 899-905.

(47) Qu, X.; Li, Z.; Xie, X.; Sui, Y.; Yang, L.; Chen, Y. Survey of composition and generation rate of household wastes in Beijing, China. Waste Manage. 2009, 29 (10), 2618-2624.

(48) Parfitt, J.; Barthel, M.; Macnaughton, S. Food waste within food supply chains: quantification and potential for change to 2050. Philos. Trans. R. Soc., B 2010, 365 (1554), 3065-3081.

(49) Churkina, G. Modeling the carbon cycle of urban systems. Ecol. Modell. 2008, 216 (2), 107-113.

(50) Zhou, C.; Huang, H.; Cao, A.; Xu, W. Modeling the carbon cycle of the municipal solid waste management system for urban metabolism. Ecol. Modell. 2015, 318, 150-156.

(51) Escamilla-Alvarado, C.; Poggi-Varaldo, H. M.; Ponce-Noyola, M. T. Bioenergy and bioproducts from municipal organic waste as alternative to landfilling: a comparative life cycle assessment with prospective application to Mexico. Environ. Sci. Pollut. Res. 2016, 23, $1-16$. 